\title{
Combining ability analysis for grain filling duration and yield traits in spring wheat (Triticum aestivum L. em. Thell.)
}

\author{
Kamaluddin*, Rishi M. Singh, Lal C. Prasad, Malik Z. Abdin ${ }^{*}$ and Arun K. Joshi \\ ${ }^{1}$ Department of Genetics and Plant Breeding, Institute of Agricultural Sciences, Banaras Hindu University, \\ Varanasi, UP, India.
}

\begin{abstract}
A diallel analysis of wheat (Triticum aestivum L. em. Thell) parents $(n=11)$ and their $F_{1}(n=55)$ and $F_{2}(n=55)$ offspring was carried out for the following four traits: grain filling duration (GFD), GFD for growing degree days (GDD), 1000 seed weight and seed yield per plant. Analysis of variance for general combining ability (GCA) and specific combining ability (SCA) displayed significant $\mathrm{F}_{1}$ and $\mathrm{F}_{2}$ general and specific combining ability effects for the four traits studied. For all the traits the GCA effects were relatively more important than the SCA effects, indicating that additive genetic effects were predominant. Crosses displaying high SCA effects for grain filling duration, seed weight and yield were observed to be derived from parents having various types of GCA effects (high $\mathrm{x}$ high, high $\mathrm{x}$ low, low $\mathrm{x}$ low and medium $x$ low). The single seed descent method can be applied to exploit additive gene effects whereas dominance gene effects could be valuable in hybrid wheat breeding programs. Among the parents, genotypes from the International Maize and Wheat Improvement Center (Centro Internacional de Mejoramiento de Maíz y Trigo, CIMMYT) as well as South Asia were found to be superior general combiners for grain filling duration. Likewise, crosses involving diverse parents from CIMMYT and South Asia showed significant SCA effects for grain filling duration and other traits.
\end{abstract}

Key words: wheat, combining ability, GCA, SCA, grain filling duration.

Received: February 2, 2006; Accepted: October 11, 2006.

\section{Introduction}

The most important yield components of wheat (Triticum aestivum L. em. Thell.) are number of kernels per spike and Kernel weight, the latter being the product of the rate and duration of grain filling (Gebeyehou et. al., 1982; Van Sanford and Mackown, 1985; Bruckner and Frohberg, 1987). Grain filling duration (GFD) is the period between flowering and physiological maturity (Przuli and Mladinov, 1999) and, in wheat, has been reported to be significantly affected by temperature and light (Wardlaw, 1970; Sofield et. al., 1977; Wiegand and Cuellar, 1981) and hence could be an important trait in terminal heat stress environments (Al-Khatib and Paulsen, 1984). Under semiarid conditions wheat lines with a longer grain filling duration produced lower yields if high water and temperature deficiency occurred during grain filling (Przulj and Mladenov, 1999). The plant genotype and environment

Send correspondence to Arun K. Joshi. Department of Genetics and Plant Breeding, Institute of Agricultural Sciences, Banaras Hindu University, Varanasi, 221005 UP, India. E-mail: joshi_vns@ yahoo.co.in.

${ }^{*}$ Present address: Centre for Transgenic Plant Development, Department of Biotechnology, Hamdard University, New Delhi, India. both influence the rate and duration of grain filling (Gallagher et. al., 1974; Metzger et. al., 1984; Bauer et. al., 1985) and significant genotypic differences for this trait have been reported in spring wheat (Mou and Kronstad, 1994; Przulj and Mladenov, 1999; Saadalla et. al. 2000; Talbert et al. 2001).

The optimum time for sowing wheat on the plains of South Asia is from November the $15^{\text {th }}$ to $25^{\text {th }}$ but in a significantly large area, principally the fourteen-million hectare South Asian rice/wheat cropping system (Hobbs and Morris, 1996; Pandey, 2005; Joshi et al., 2007a), wheat sowing often gets delayed due to the late harvesting of rice (Joshi et al., 1997; Arun et al., 2003). In about four to five million hectares wheat-sowing occurs after December $15^{\text {th }}$, resulting in high wheat yield losses due to the reduced growth and development period available before harvest (Joshi and Chand, 2002; Arun et al., 2003; Joshi et al., 2007b). Almost the whole of this late sown area is in the eastern Gangetic plains, most of which occurs in the 9.5 million hectare North Eastern Plain Zone (NEPZ) of India where the average wheat yield is only 2.7 tonnes $(\mathrm{t}) \mathrm{ha}^{-1}$ compared to the $4.7 \mathrm{t} \mathrm{ha}^{-1}$ in the Indian state of Punjab (Joshi et al., 2007b). The North Western Plains Zone (NWPZ) of India (extend- 
ing from the state of Punjab to western Uttar Pradesh) has an area almost equal to that of the NEPZ and is the most important wheat-producing zone of Indian, with an average wheat yield of about $4 \mathrm{t} \mathrm{ha}^{-1}$. Resource conservation technologies are spreading rapidly in the North Eastern Plains Zone (NEPZ) region such that zero-till sowing accounted for about $10^{5}$ ha in the $2005 / 2006$ cropping season (Joshi et al., 2007b). However, due to the domination of long duration rice varieties such as MTU 7029, late transplanting, water stagnation and other related factors it is unlikely that, in the near future, the sowing of wheat will be advanced in the NEPZ region by more than two to three weeks. The warm and humid NEPZ region, classified as a Mega Environment 5 by Braun et al. (1992), best supports wheat varieties that are heat tolerant or display rapid grain filling. Grain filling duration is an important factor when wheat is grown under conditions of high temperature and water stress and it has been suggested (Wiegand and Cuellar, 1981) that for such environments wheat lines should be developed with a shorter grain filling duration. Better information on the factors involved in the grain filling duration trait, including the gene effects controlling this trait and the combining ability of different wheat lines, could result in the development of heat tolerant or rapid grain filling wheat lines. In barley a long grain filling duration is dominant over a shorter grain filling duration (Aksel and Johnson, 1961) but little information is available on the factors involved in the wheat grain filling duration trait. It has been suggested that the inheritance of the grain filling duration trait is polygenic in wheat because this trait shows continuous variability in wheat (Xie and Zhang, 1981) and some workers have reported that both additive and dominance gene actions are associated with wheat grain filling duration (Saadalla et. al., 2000; Yang et al., 2002).

The study described in this paper was undertaken to determine the gene effects and combining ability of grain filling duration and yield traits in some wheat lines used in India.

\section{Materials and Methods}

We investigated wheat (Triticum aestivum L. em. Thell.) parent plants $(n=11)$ and their $F_{1}(n=55)$ and $F_{2}$ $(\mathrm{n}=55)$ offspring, the parent plants being selected from the wheat germplasm collection at Banaras Hindu University (WGC-BHU), Varanasi, India based on their grain filling duration. Details of the lines used, including their provenance, are given in Table 1 . Some lines came from the International Maize and Wheat Improvement Center, Centro Internacional de Mejoramiento de Maíz y Trigo (CIMMYT), Mexico D.F., Mexico.

Parent plants differing in grain filling duration were crossed in all possible manners during the 1999-2000 cropping season to produce $F_{1}$ and $F_{2}$ offspring. The parent plants and $F_{1}$ and $F_{2}$ offspring were then planted in a randomized block design with three replications at the Agriculture Research Farm, Institute of Agricultural Sciences, Banaras Hindu University, Varanasi, India $\left(25.2^{\circ} \mathrm{N}\right.$, $\left.83.0^{\circ} \mathrm{E}\right)$ on December $25^{\text {th }} 2001-2002$. This site is in the eastern Gangetic plains of India and has a loam alluvial soil with a neutral $\mathrm{pH}$ of 7.2. Agronomic practices recommended for normal fertility were followed and the soil was fertilized with $60 \mathrm{~kg} \mathrm{~N}^{-1}$ of $\mathrm{P}_{2} \mathrm{O}_{5}$ and $40 \mathrm{~kg} \mathrm{ha}^{-1} \mathrm{~K}_{2} \mathrm{O}$ at sowing and $60 \mathrm{~kg} \mathrm{~N} \mathrm{ha}^{-1}$ at sowing, $30 \mathrm{~kg} \mathrm{~N} \mathrm{ha}^{-1}$ at the first irrigation, 21 days after sowing, and $30 \mathrm{~kg} \mathrm{~N} \mathrm{ha}^{-1}$ at the second irrigation, 45 days after sowing.

Each of the line of parents and $F_{1}$ offspring were grown in four three-meter long rows with a spacing of $25 \mathrm{~cm} \times 5 \mathrm{~cm}$, the plot size being kept same for the $\mathrm{F}_{2}$ generation but the number of rows was increased to 12 for each cross. Observations for the different traits were recorded on 20 random plants for the parent plants and $\mathrm{F}_{1}$ offspring and 250 plants for the $F_{2}$ offspring and the plants were tagged

Table 1 - Pedigree of the parent wheat plants and their grain filling duration (GFD) periods in days.

\begin{tabular}{llcc}
\hline Parent line & Pedigree & Source $^{1}$ & GFD \\
\hline HP 1633 & RL6010/6* Sonalika & WGC-BHU, India & 26 \\
PBW 343 (Attila) & ND/VG1944//KAL//BB/3/YACO 'S'/4//VEE?5 'S' & CIMMYT & 35 \\
Bagula & TTR “S”/JUN “S” & CIMMYT & 41 \\
Veery 'S' & KUZ/BUHO//KAL/B6 & CIMMYT & 32 \\
PAVON 76 & VCM//CNO 'S'/7C/3/KAL/BB & CIMMYT & 27 \\
HP 1731 & LIRA 'S'// PRL 'S'/TONI & WGC-BHU, India & 28 \\
HW 1084 & HW1042/NP807 & WGC-BHU, India & 40 \\
HD 2285 & 249/HD2160//HD2186 & WGC-BHU, India & 28 \\
HP 1102 & 8156 (B)/Nad63 & WGC-BHU, India & 34 \\
KRL-1-4 & Kharchia/WL711 & WGC-BHU, India & 36 \\
K 9107 & K8101/K68 & WGC-BHU, India & 29 \\
\hline
\end{tabular}

${ }^{1}$ Key: CIMMYT = Centro Internacional de Mejoramiento de Maíz y Trigo (International Maize and Wheat Improvement Center, Mexico D.F., Mexico); WGC-BHU = Wheat Germplasm Collection, Banaras Hindu University, India. 
prior to heading. The three quantitative traits recorded per plant were: grain filling duration (GFD), 1000 seed weight $\left(\mathrm{S}_{\mathrm{W}}\right)$ and seed yield $\left(\mathrm{S}_{\mathrm{Y}}\right)$. Grain filling duration was also converted to growing degree days (GDD) by summing the daily degree days $\left(T_{n}\right)$ computed as $\left(T_{n}\right)=\left(T_{\max }+T_{\min }\right) / 2$ $-T_{b}$, where, $T_{\max }$ and $T_{\min }$ are the maximum and minimum daily temperatures and $\mathrm{T}_{\mathrm{b}}$ is the base temperature $\left(5^{\circ} \mathrm{C}\right)$ below which no development occurs (Yasuda and Shimoyama, 1965). The mean genotype values were subjected to combining ability by diallel analysis, method 2, model I (Griffing, 1956). Analysis of variance (ANOVA) and general and specific combining ability (GCA and SGA) was carried out for all traits, the $\mathrm{F}$ test being used to determine significant differences. The statistical tests were carried out using the INDOSTAT program.

\section{Results}

Analysis of variance indicated significant differences between parents for all four traits studied (Table 2). The coefficient of variation was highest for seed yield, followed by growing degree days and then grain filling duration (Table 2). For both the $F_{1}$ and $F_{2}$ generations the general and specific combining ability ANOVA results for all four traits were significant (Table 3 ), with the general effects being higher than the specific effects. This suggests that the parents used in the study differed significantly for general as well as specific combining ability and that additive genetic effect were predominant. The general combining ability effects of the parents indicated that the CIMMYT lines Veery 'S' and Pavon 76 and the WGC-BHU lines HP 1731 and HD 2285 were good general combiners for the grain filling duration trait (Table 4). The CIMMT Veery ' $S$ ' line was also a good general combiner with regard to the GDD, $\mathrm{S}_{\mathrm{w}}$ and $\mathrm{S}_{\mathrm{y}}$ traits (Table 4) and the CIMMYT line BW 343 (Attila) displayed good performance with respect to the general combining ability of different traits (Table 4).

The specific combining ability effects of the crosses for grain filling duration and the other traits examined are presented in Table 5. Not all crosses demonstrated significant specific combining ability effects for different traits. Only eight crosses (PBW 343/Bagula, Bagula/Veery 'S', HP 1731/KRL-1-4, PBW 343/HP 1102, Bagula/HW 1084, Veery 'S'/HW 1084, HP 1731/K 9107 and HW 1084/K 9107) of the 55 crosses investigated showed desirable significant grain filling duration specific combining ability effects in both generations, and only two crosses (PBW 343/Bagula and Bagula/Veery 'S') exhibited significant and desirable GDD effects. Desirable significant specific combining ability effects were recorded for the HP 1731/KRL-1-4 cross in regard to $S_{w}$ and for the PBW 343/HP 1102 cross in respect to $S_{w}$ and $S_{y}$.

\section{Discussion}

Table 2 - Analysis of variance and coefficient of variation (CV) for grain filling duration (GFD), growing degree days (GDD), 1000 seed weight (SW) and seed yield (SY) per plant for the 11 wheat parents involved in the diallel cross.

\begin{tabular}{lccccc}
\hline \multicolumn{5}{c}{ Mean squares } \\
\hline Source of variation & DF & GFD & GDD & SW & SY \\
\hline Replication & 2 & 0.082 & 4.88 & 2.27 & 0.14 \\
Treatment & 120 & $57.75^{* *}$ & $18922.46^{* *}$ & $260.07^{* *}$ & $55.27^{* *}$ \\
Error & 240 & 0.79 & 1845.72 & 3.48 & 0.32 \\
CV\% & & 28.00 & 29.00 & 17.00 & 33.00 \\
\hline
\end{tabular}

**Significant at $\mathrm{p}=0.01$ by the $\mathrm{F}$ test.

Table 3 - Analysis of variance for combining ability for the grain filling duration (GFD), GFD for growing degree days (GDD), 1000 seed weight (SW) and seed yield (SY) per plant for the $\mathrm{F}_{1}$ and $\mathrm{F}_{2}$ offspring of the 11 wheat parents involved in the diallel cross.

\begin{tabular}{lcccccc}
\hline & & \multicolumn{5}{c}{ Mean squares } \\
\cline { 3 - 7 } Source of variation & Generation & DF & GFD & GDD & SW & SY \\
\hline GCA & $\mathrm{F}_{1}$ & 10 & $22.34^{* *}$ & $6818.43^{* *}$ & $39.83^{* *}$ & $34.22^{* *}$ \\
& $\mathrm{~F}_{2}$ & 10 & $13.43^{* *}$ & $5747.67^{* *}$ & $44.31^{* *}$ & $17.21^{* *}$ \\
SCA & $\mathrm{F}_{1}$ & 55 & $17.79^{* *}$ & $5440.63^{* *}$ & $11.38^{* *}$ & $16.52^{* *}$ \\
& $\mathrm{~F}_{2}$ & 55 & $22.85^{* *}$ & $6955.50^{* *}$ & $14.95^{* *}$ & $26.63^{* *}$ \\
Error & $\mathrm{F}_{1}$ & 130 & 0.29 & 961.77 & 0.17 & 0.100 \\
& $\mathrm{~F}_{2}$ & 130 & 0.22 & 888.27 & 0.032 & 0.070 \\
\hline
\end{tabular}

**Significant at $\mathrm{p}=0.01$ by the $\mathrm{F}$ test. 
Table 4 - Estimates of general combining ability (GCA) effects for the $F_{1}$ and $F_{2}$ offspring of 11 wheat parents and their mean performance (MP) for grain filling duration (GFD), GFD for growing degree days (GDD), 1000 seed weight (SW) and seed yield (SY) per plant.

\begin{tabular}{|c|c|c|c|c|c|c|c|c|c|c|c|c|}
\hline \multirow[b]{3}{*}{ Parents } & \multicolumn{3}{|c|}{ GFD } & \multicolumn{3}{|c|}{ GDD } & \multicolumn{3}{|c|}{ SW } & \multicolumn{3}{|c|}{ SY } \\
\hline & \multicolumn{2}{|c|}{ GCA effects } & \multirow[t]{2}{*}{ MP } & \multicolumn{2}{|c|}{ GCA effect } & \multirow[t]{2}{*}{ MP } & \multicolumn{2}{|c|}{ GCA effect } & \multirow[t]{2}{*}{ MP } & \multicolumn{2}{|c|}{ GCA effect } & \multirow[t]{2}{*}{ MP } \\
\hline & $\mathrm{F}_{1}$ & $\mathrm{~F}_{2}$ & & $\mathrm{~F}_{1}$ & $\mathrm{~F}_{2}$ & & $\mathrm{~F}_{1}$ & $\mathrm{~F}_{2}$ & & $\mathrm{~F}_{1}$ & $\mathrm{~F}_{2}$ & \\
\hline HP 1633 & 0.13 & -0.24 & 25.67 & 4.47 & -0.25 & 463.77 & 0.09 & $-0.38 * *$ & 40.10 & 0.24 & -0.08 & 21.37 \\
\hline Bagula & $1.16^{* *}$ & $0.58 * *$ & 40.67 & -12.21 & $-23.27 * *$ & 503.31 & $-0.35^{* *}$ & $-0.16^{* *}$ & 32.53 & -0.14 & $-0.36^{* *}$ & 20.47 \\
\hline PBW 343 & $1.18^{* *}$ & $0.91 * *$ & 35.00 & 13.20 & 2.29 & 559.43 & $2.32 * *$ & $1.31^{* *}$ & 39.03 & $2.84^{* *}$ & $2.79 * *$ & 27.23 \\
\hline Veery 'S' & $-1.51^{* *}$ & $-1.91^{* *}$ & 32.33 & $-27.64 * *$ & $-35.15^{* *}$ & 559.63 & $0.50^{* *}$ & $0.49 * *$ & 39.17 & $2.07 * *$ & $0.47 * *$ & 28.27 \\
\hline PAVON 76 & $-1.02^{* *}$ & -0.06 & 25.33 & -12.72 & 12.12 & 487.27 & $-1.06^{* *}$ & $-0.38 * *$ & 33.53 & $-1.94 * *$ & $-0.47 * *$ & 22.30 \\
\hline HP 1731 & $-1.82^{* *}$ & $-0.99 * *$ & 27.33 & -22.63 & 3.28 & 529.13 & $1.65^{* *}$ & $1.43 * *$ & 40.10 & $-0.47 * *$ & $1.07 * *$ & 28.33 \\
\hline HW 1084 & $1.26^{* *}$ & $1.76 * *$ & 41.67 & $34.84 * *$ & $46.89 * *$ & 771.37 & $-2.43 * *$ & $-1.90 * *$ & 33.10 & $-0.90^{* *}$ & $-0.58 * *$ & 21.20 \\
\hline HD 2285 & $-1.02^{* *}$ & $0.91 * *$ & 27.67 & $-28.19^{* *}$ & 11.67 & 442.63 & $-2.66 * *$ & $-3.05 * *$ & 37.47 & $-1.81 * *$ & $-0.60 * *$ & 19.43 \\
\hline HP 1102 & $2.00^{* *}$ & 0.09 & 33.00 & $33.71^{* *}$ & -2.49 & 567.33 & $-0.74 * *$ & $-1.19 * *$ & 35.37 & $-0.86^{* *}$ & $-0.61 * *$ & 20.20 \\
\hline KRL-1-4 & $0.57^{* *}$ & $-0.45^{* *}$ & 36.00 & 17.80 & -11.17 & 634.70 & -0.06 & -0.10 & 40.03 & $-1.03^{* *}$ & $-1.63^{* *}$ & 28.43 \\
\hline K 9107 & $-0.92^{* *}$ & $-0.60^{* *}$ & 29.00 & -0.63 & -3.92 & 530.27 & $2.75^{* *}$ & $3.93 * *$ & 44.13 & $2.01 * *$ & -0.02 & 33.43 \\
\hline $\mathrm{Xp}$ & 34.02 & 32.65 & & 610.43 & 570.77 & & 36.65 & 34.93 & & 20.59 & 18.78 & \\
\hline $\mathrm{SE}(\mathrm{gi}) \pm$ & 0.14 & 0.12 & & 8.20 & 7.88 & & 0.10 & 0.04 & & 0.08 & 0.07 & \\
\hline SE (gi-gj) & 0.20 & 0.18 & & 12.16 & 11.68 & & 0.16 & 0.07 & & 0.12 & 0.10 & \\
\hline
\end{tabular}

**Significant at $\mathrm{p}=0.01$ by the $\mathrm{F}$ test.

Key: $\mathrm{Xp}=$ grand mean of Parents, $\mathrm{F}_{1}$ and $\mathrm{F}_{2} ; \mathrm{SE}=$ Standard error; gi $=$ General combining ability effects for line $\mathrm{i}$; gj = General combining ability effects for line $\mathrm{j}$.

Table 5 - Estimates of desirable specific combining ability (SCA) effects for the $F_{1}$ and $F_{2}$ offspring of 11 wheat parents for grain filling duration (GFD), GFD for growing degree days (GDD), 1000 seed weight (SW) and seed yield (SY) per plant.

\begin{tabular}{|c|c|c|c|c|c|c|c|c|c|c|c|c|c|c|c|c|}
\hline \multirow{3}{*}{$\begin{array}{l}\text { Cross } \\
\text { combinations }\end{array}$} & \multicolumn{16}{|c|}{ SCA effects } \\
\hline & \multicolumn{4}{|c|}{ GFD } & \multicolumn{4}{|c|}{ GDD } & \multicolumn{4}{|c|}{ SW } & \multicolumn{4}{|c|}{ SY } \\
\hline & $\mathrm{F}_{1}$ & Mean & $\mathrm{F}_{2}$ & Mean & $\mathrm{F}_{1}$ & Mean & $\mathrm{F}_{2}$ & Mean & $\mathrm{F}_{1}$ & Mean & $\mathrm{F}_{2}$ & Mean & $\mathrm{F}_{1}$ & Mean & $\mathrm{F}_{2}$ & Mean \\
\hline PBW 343/Bagula & $-10.36^{* *}$ & 26.00 & $-11.14^{* *}$ & 23.00 & $-135.36 * *$ & 476.07 & $-162.55^{* *}$ & 387.23 & & & & & & & & \\
\hline Bagula/Veery 'S' & $-7.00 * *$ & 26.67 & $6.32 * *$ & 25.00 & $-100.32 * *$ & 470.27 & $-93.27 * *$ & 418.63 & & & & & & & & \\
\hline HP 1731/KRL-1-4 & $-5.44 * *$ & 27.33 & $-3.88 * *$ & 27.33 & & & & & $4.96^{* *}$ & 43.20 & $2.94 * *$ & 39.20 & & & & \\
\hline PBW 343/HP 1102 & $-4.54 * *$ & 32.67 & $-2.65^{* *}$ & 31.00 & & & & & $3.00 * *$ & 41.23 & $2.18^{* *}$ & 37.23 & $5.63^{* *}$ & 28.20 & $4.63^{* *}$ & 25.60 \\
\hline Bagula/HW 1084 & $-3.44 * *$ & 33.00 & $-3.32 * *$ & 31.67 & & & & & & & & & & & & \\
\hline Veery ‘S’/HW 1084 & $-3.11 * *$ & 30.67 & $-5.50 * *$ & 27.00 & & & & & & & & & & & & \\
\hline HP 1731/K 9107 & $-3.29 * *$ & 28.00 & $-3.06^{* *}$ & 27.00 & & & & & & & & & & & & \\
\hline HW 1084/K 9107 & $-2.03 * *$ & 32.33 & $-4.47 * *$ & 29.33 & & & & & & & & & & & & \\
\hline $\mathrm{Xp}$ & 34.03 & 32.65 & & & 610.44 & 570.77 & & & 36.66 & 34.93 & & & 20.56 & 18.78 & & \\
\hline SE Sij & 0.48 & 0.43 & & & 28.74 & 27.62 & & & 0.37 & 0.16 & & & 0.28 & 0.24 & & \\
\hline SE (Sij-Sik) & 0.73 & 0.65 & & & 42.13 & 40.49 & & & 0.56 & 0.25 & & & 0.43 & 0.36 & & \\
\hline
\end{tabular}

** Significant at $\mathrm{p}=0.01$ by the $\mathrm{F}$ test.

Key: $\mathrm{Xp}=$ grand mean of Parents, $\mathrm{F}_{1}$ and $\mathrm{F}_{2} ; \mathrm{SE}=$ Standard error; $\mathrm{Sij}=$ Specific combining ability effects between ith and jth lines; Sik = Specific combining ability effects between ith and kth lines.

Analysis of variance indicated significant differences between parent plants for all the four traits studied (Table 2). Parent plants with the same number of days to physiological maturity differed in grain filling duration due to difference in the number of days to anthesis. The combining ability analyses showed that both general and specific combining ability effects played an important role in the control of the grain filling duration of the genotypes studied, with the general effects being greater than the specific effects.
This suggests a prominent role for additive genetic effects, although the significance of specific combining ability effects indicates that dominance and epistasis were also involved in the expression of the traits studied. Similar results have also been reported in wheat by other workers (Ahmed et. al., 1991; Mou and Kronstad, 1994; Sharma et. al., 1996; Sharma and Pawar, 2000). Przuli and Mladenov (1999) observed the presence of additive and dominance as well as epistatic interactions in the expression of grain fill- 
ing duration in wheat, while Yang et al., (2002) reported that both additive and dominance gene effects were associated with grain filling duration in wheat plants subjected to heat stress. In our study, the greater magnitude of additive effects compared to non-additive effects suggests that selection for shorter grain filling duration might be effective in the early segregating generations.

The magnitude and direction of combining ability effects are known to be useful in selecting parent plants in crop improvement programs (Mather and Jinks, 1971). In our study, crosses displaying high specific combining ability effects for grain filling duration, seed weight and yield were derived from parents with various types of general combining ability effects (high $\mathrm{x}$ high, high $\mathrm{x}$ low, low $\mathrm{x}$ low and medium $x$ low). The occurrence of crosses with high specific combining ability effects involving low $\mathrm{x}$ low general combining ability parents indicates that although the parents in such crosses lacked additive gene effects compared to high general combining ability parents, heterozygotes were highly responsive to the environment due to non additive effects such as dominance and epistasis (Jinks and Jones, 1958). It has been suggested (Joshi and Sharma, 1984; Singh et. al., 1986) that intermating between crosses followed by selection may be a useful strategy for obtaining desirable segregants in crosses from high $\mathrm{x}$ low and low $\mathrm{x}$ low general combining ability parents. The superior performance of crosses between parents from diverse origins (CIMMYT, Mexico and South Asia) also demonstrated the role of a wider genetic base in the crossing program (Kronstad, 1996).

Our results show the importance of both additive and non-additive gene effects in the expression of grain filling duration and yield related traits in wheat. It appears, therefore, that single seed decent or the bulk method of handling segregating generations can also be used to utilize additive or additive $\mathrm{x}$ additive gene effects to manipulate grain filling duration for developing better yielding cultivars suited to different environmental conditions (Przulj and Maladenov, 1999), especially terminal heat stress. Dominance genetic effects will be valuable in wheat breeding programs when hybrid seed production is made economically feasible through an efficient cytoplasmic male sterility system (Pickett, 1993). It also seems that parent plants with better general and specific combining ability for grain filling duration need to be given greater consideration when developing varieties for warmer areas such as eastern and central South Asia where wheat generally is allowed less time to complete its life cycle.

\section{Acknowledgments}

The first author acknowledges the financial support given by University Grants Commission, N. Delhi, India for providing a fellowship during the course of this study.

\section{References}

Ahmed Z, Singh KN and Srivastava VK (1991) Grain quality characters in wheat. Indian J Genet 51:84-89.

Aksel R and Johnson LPV (1961) Genetic studies in sowing to heading and heading to ripening periods in barley and their relation to yield and yield components. Can J Genet Cytol 3:242-259.

Al-Khatib K and Paulsen GM (1984) Mode of high temperature injury to wheat during grain development. Physiol Plant 61:363-368.

Arun B, Joshi AK, Chand R and Singh BD (2003) Wheat somaclonal variants showing, earliness, improved spot blotch resistance and higher yield. Euphytica 132:235-241.

Bauer A, Frank AB and Black AL (1985) Estimation of Spring wheat grain dry matter assimilation from air temperature. Agron J 77:743-752.

Braun H-J, Pfeiffer WH and Pollmer WG (1992) Environments for selecting widely adapted spring wheat. Crop Sci 32:1420-1427.

Bruckner PL and Frohberg RC (1987) Rate and duration of grain fill in spring wheat. Crop Sci 27:451-455.

Gallagher JN, Biscoe PV and Hunter B (1974) Effects of drought on grain growth. Nature 264:541-542.

Gebeyehou GD, Knott R and Baker RJ (1982) Rate and duration of grain filling on durum wheat varieties. Crop Sci 22:337-340.

Hobbs P and Morris M (1996) Meeting South Asia's future food requirements from rice-wheat cropping systems: Priority issues facing researchers in the post-Green revolution era. NRG paper 96-01, CIMMYT, Mexico, 46 pp.

Jinks JL and Jones RM (1958) Estimation of components of heterosis. Genetics 43:223-224.

Joshi AK and Sharma GS (1984) Genetics of flag leaf area in wheat Triallel analysis. Indian J Genet 44:399-405.

Joshi AK, Singh RH and Rai B (1997) Effect of three generations of backcrossing on the maturity duration, grain yield and its attributes in certain inter varietal crosses of wheat. Malaysian Appl Biol 26:7-12.

Joshi AK and Chand R (2002) Variation and inheritance of leaf angle, and its association with spot blotch (Bipolaris sorokiniana) severity in wheat (Triticum aestivum). Euphytica 124:283-291.

Joshi AK, R Chand, B Arun, RP Singh and R Ortiz (2007a) Breeding crops for reduced-tillage management in the intensive, rice-wheat systems of South Asia. Euphytica 153:135-151.

Joshi AK, Mishra B, Chatrath R, Ortiz-Ferrara G and Singh RP (2007b) Wheat improvement in India: Present status, emerging challenges and future prospects. Euphytica (in press).

Kronstad WE (1996) Genetic diversity and the free exchange of germplasm in breaking yield barriers. In: Reynolds MP, Rajaram S and McNab A (eds) Increasing Yield Potential in Wheat: Breaking the Barriers. CIMMYT, Mexico, D.F., pp 19-27.

Mather K and Jinks JL (1971) Biometrical Genetics. London, Chapman \& Hall.

Metzger DD, Czplewski SJ and Rasmusson DC (1984) Grain fill duration and yield in spring barley. Crop Sci 24:1101-1105.

Mou B and Kronstad WE (1994) Duration and rate of grain filling in selected winter wheat populations. I. Inheritance. Crop Sci 34:833-837. 
Pandey SP, Kumar S, Kumar U, Chand R and Joshi AK (2005) Sources of inoculum and reappearance of spot blotch of wheat in rice-wheat cropping system in eastern India. European J Plant Patho1 11:47-55.

Pickett AA (1993) Hybrid wheat: Results and problems. Adv Plant Breed, Suppl J Plant Breed 15:1-259.

Przuli N and Mladenov N (1999) Inheritance of grain filling duration in spring wheat. Plant Breed 118:517-521.

Saadallah MM and Ghandorah MO (2000) Inheritance of grain fill parameters in wheat under wheat stressful and non-stressful environments. Arab University, J Agric Sci 8:137-153.

Sharma PK, Garg DK and Sharma PC (1996) Genetic characterization of some quantitative characters in wheat. Indian $\mathrm{J}$ Genet 56:281-284.

Sharma PK and Pawar IS (2000) Genetic architecture of some wheat crosses through triple test cross method. Indian $\mathrm{J}$ Genet Plant Breed 48:45-48.

Singh RK, Ahmed Z, Singh YP and Singh KN (1986) Combining ability studies for some metric traits in bread wheat. Indian J Genet 46:304-310.

Sofield I, Evans LT, Cook MG and Wardlaw IF (1977) Factors influencing the rate and duration of grain filling in wheat. Aust J Plant Physiol 4:785-797.
Talbert LE, Lanning SP, Murphy RL and Martin JM (2001) Grain fill duration in twelve hard red spring wheat crosses: Genetic variation and association with other agronomic traits. Crop Sci 41:1390-1395.

Van Sanford DA and Mackown CT (1985) Cultivar differences in nitrogen remobilization during grain-fill in soft red winter wheat. Crop Sci 27:295-300.

Wardlaw IF (1970) The early stages of grain development in wheat: Response to light and temperature in a single variety. Aust J Bio Sci 23:765-744.

Wiegand CL and Cuellar JA (1981) Duration of grains filling and Kernel weight as affected by temperature. Crop Sci 21:95-101.

Xie RS and Zhang ZH (1981) Investigation of the genetic control of earliness in wheat based upon character correlations and heritability. Sci Agric Sin 3:16-24.

Yang J, Sears RG, Gill BS and Paulsen GM (2002) Quantitative and molecular characterization of heat tolerance in hexaploid wheat. Euphytica 126:275-282.

Yasuda S and Shimoyama H (1965) Analysis of internal factors influencing heading time of wheat verities. Berlin Ohera Institute 13:23-38.

Associate Editor: Ernesto Paterniani 